\section{Natalia S. Hrudkina \\ Postdoctoral Researcher, Departament of Metal Forming, Machine Building Faculty, Donbass State Engineering Academy, Ukraine}

Leila I. Aliieva

Doctor of Thecnical Sciences, Departament of Metal Forming Machine Building Faculty, Donbass State Engineering Academy, Ukraine

\title{
Modeling of Cold Extrusion Processes Using Kinematic Trapezoidal Modules
}

In this paper, we analyze the features of using an axial trapezoidal module in design schemes with an adjacent lower module of various configurations. As adjacent kinematic modules, a rectangular rigid, longitudinal-transverse flow and a trapezoidal kinematic module with a rectilinear inclined boundary are chosen. It has been established that optimization in relative velocity of metal flow in the backward direction is possible only with a combination of kinematic modules with a radial component of one direction (sign) and impossible in other cases The paper shows practical realization of the authors' approach for the particular case of modeling of the process of combined radial-backward extrusion of the end-capped parts with a flange. The deviation of the theoretically obtained estimates of the force parameters of the process and shaping does not exceed 10 - 15\%. Author-proposed computations for the powers of shearing forces can be successfully used for engineering-friendly modeling of more complex processes of the cold combined extrusion with additional taking into account the availability of metal flow in the forward, backward and radial directions.

Keywords: deformation process; combined extrusion; energy method; kinematic module; deformation pressure.

\section{INTRODUCTION}

Ensuring the competitiveness of products in the branches of mechanical engineering in modern conditions is inextricably linked with the development and reclamation of such effective methods of metal processing by pressure, as cold volume forging (CVF) $[1,2]$. Technological methods of CVF differ in a variety of possibilities and high efficiency in comparison with other processes of forming of details. Cold extrusion processes demonstrate a steady tendency not only to increase the volume of production of precision workpieces, but also to expand the range of stamped parts and materials. This is due to new methods of transverse and combined extrusion [2-4].

Currently, an effective theoretical method for studying cold extrusion processes is the energy method (power balance method). Within the framework of using this method, the selection of appropriate functions describing a kinematically possible velocity field (KPVF) has key significance, satisfying the boundary conditions, the condition of incompressibility of material and the condition of continuity of normal velocity component. The application of the kinematic modules method allows to describe the complex flow schemes with the help of a complex of elementary unified modules [5]. As a total estimate of the reduced pressure is the sum of the reduced pressures of the modules included in this calculation scheme. However, one of the characteristic features of use of the energy method is the presence of

Received: October 2019, Accepted: January 2020

Correspondence to: Dr Natalia S. Hrudkina

Donbass State Engineering Academy, Akademichna

(Shkadinova) Str. 72, 84313 Kramatorsk, Ukraine

E-mail: vm.grudkina@gmail.com

doi:10.5937/fme2002357H

(C) Faculty of Mechanical Engineering, Belgrade. All rights reserved sufficiently labor-intensive procedures for the analysis of the force and kinematic regime of the deformation process $[4,6]$. Therefore, studies of the effectiveness of methods of simplifying the components of the reduced deformation pressure and the development of recommendations for the use of kinematic mules in new design schemes are relevant. This will help to eliminate the difficulties of using the method of kinematic modules and promote the introduction of cold combined extrusion processes in production.

A number of papers are devoted to theoretical, finite element and experimental studies of basic and combined schemes of cold extrusion processes [6-16]. In the paper [6] a finite-element method is used to study the effect of the design parameters of the die on the production of hollow brass parts by cold direct extrusion and expansion on a cone punch. In the paper [7] a finite element analysis of the radial-backward extrusion of hollow parts with a flange is carried out and the influence of friction conditions and the radius of curvature of the matrix on the force parameters of the deformation process is investigated. It was found that under certain conditions, the size of the part in height could be decreased due to the deformation process compared to the initial height of the workpiece. In the paper [8] the authors investigated the influence of gap height, mandrel radius on the formation and oscillation of the load in the process of successive radial-direct extrusion. The reliability of the results of finite element modeling is confirmed by experimentally obtained data presented in the literature. Of particular interest are the papers [912] based on the basis of various modifications of the energy method aimed at investigating of based and combined extrusion processes. Papers [9, 10] are dedicated studying the process of combined backward-forward extrusion by the method of upper bound ele- 
ment technique using arbitrarily oriented triangular elements, combined with the method of finite elements (FEM). Perig $(2014,2015)$ has applied Kudo's rigid block methods with one [11] and two [12] degrees of freedom to derivation of upper bound method-based estimations of energy-power parameters during angular extrusion process. In paper $[13,14]$ the analysis of the combined radial-backward extrusion process in a conical matrix is carried out. Trapezoidal kinematic modules with a rectilinear inclined boundary that does not contain the axis of symmetry are used. However, the values for the total power are found numerically and in the explicit form were not obtained. Perig et al (2013, 2019) have proposed non-linear regression-based engineering estimations for finite element method-derived numerical results for ECAE-induced deformations [1516]. Thus, studies of cold extrusion processes are limited to finite-element analysis, theoretical calculations with using of elementary triangular, rectangular and trapezoidal non-axial modules. At the same time, the possibilities of simplifying calculations in order to obtain analytical dependences of the studied values are not fully used. Thus, the methods of constructing velocity fields and simplifying further calculations of the force parameters of the process and the shape change require clarification and development. There is also a need to develop generalizing recommendations for the use of calculations of known kinematic modules and features of their use in new computational schemes.

The purpose of the work was to analyze the features of the use of the axial trapezoidal kinematic module in the design schemes with adjacent lower modules of different configurations.

\section{PRESENTATION OF THE MAIN MATERIAL}

The first key stage of using the energy method can be considered the selection of functions (sets of functions) that describe KPVF. No less important is the second stage - the stage of searching of tools to simplify the components of the energy equation, which will allow to obtain the given pressure in an analytical form. This applies primarily to computational schemes containing trapezoidal and triangular modules with curvilinear boundaries, when trapezoid kinematic modules with a curvilinear sloped boundary are used.

The question of using the kinematic parameters of the process as variable with the possibility of further optimization of these parameters remains open. The first attempts to solve the problem of simplifying the calculations of the power of deformation forces the possibility of using linearization of the intensity of deformation rate was discussed $[17,18]$.

Another technique to simplify calculations of a reduced pressure in analytical form is searching for a family of functions describing the necessary inclined curvilinear boundary of the kinematic module that allows to obtain the power of deformation, friction and shear forces [19]. This method is based on the use of limit functions as solutions to some differential equation. In the future, this allows us to obtain an expression of the intensity of deformation rates in the form acceptable for further integration over the region of the kinematic module. Another method of simplifying the reduced pressure components of the reduced pressure is the use of upper estimates of the power of deformation forces according to the Cauchy-Bunyakovsky formulas or cubature formulas $[20,21]$. It may also be necessary to simplify the power of shear and friction forces taking into account the KPVF for modules with curvilinear boundaries. Obtaining the function of the reduced pressure in an analytical form will allow optimization for the selected variable parameters. Taking into account the perspectivity for the introduction of combined extrusion processes in the production, it is necessary, first of all, to analyze kinematic modules with some degrees of freedom of metal flow.

As an internal kinematic module 1, an axial trapezoidal module with an inclined line is widely used (Figure 1).

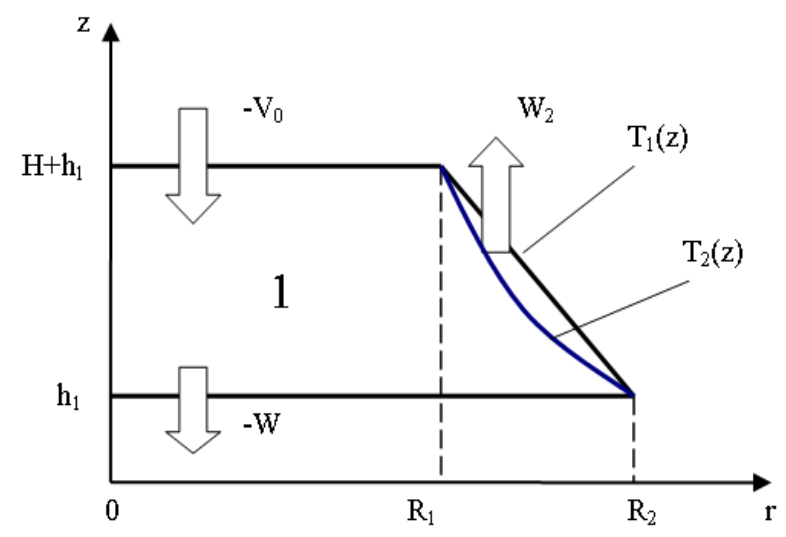

Figure 1. Axial trapezoidal kinematic module with straight $T=T_{1}(z)$ and curvilinear $T=T_{2}(z)$ inclined borders

This module can be used with the lower adjacent of various configurations and rigid kinematic modules bordering the upper and inclined limits. In this case, the inclined boundary in the simplest case can be in the form of a straight line, in general - a curve reflecting the nature of the metal flow. This kinematic module can be used for modeling of the flow in combined extrusion processes with two degrees of metal flow in the forward and reverse directions.

We consider KPVF of module 1 in general form:

$$
\left\{\begin{array}{l}
V_{z}=-V_{0} \frac{R_{1}^{2}}{T^{2}(z)}+W_{2}\left(1-\frac{R_{1}^{2}}{T^{2}(z)}\right), \\
V_{r}=-\frac{r \cdot R_{1}^{2}}{T^{3}(z)} T^{\prime}(z)\left(V_{0}+W_{2}\right) .
\end{array}\right.
$$

Using for (1) in the simplest case the rectilinear inclined boundary of the flow interface (rectilinear inclined boundary of the flow interface), we obtain the co-relation [19]:

$$
N_{\partial}=\frac{2 \pi \sigma_{S}}{9 k^{2}} R_{1}^{2}\left(V_{0}+W_{2}\right)\left(\left(4+3 k^{2}\right)^{3 / 2}-8\right) \ln \frac{R_{2}}{R_{1}},
$$

where $T_{1}(z)=k\left(z-h_{1}\right)+R_{2} ; k=T_{1}^{\prime}(z)=\frac{R_{1}-R_{2}}{H}$.

The inefficiency of using linearization to obtain the power of deformation forces for a curvilinear boundary of a general form is demonstrated in [13]. The use of the 
upper bound is also difficult because of the complexity of the integrand. Therefore, as an alternative method, the search for a "convenient" function satisfying these conditions is chosen and does not cause difficulties in further calculations.

In this regard, as a curvilinear face, we choose a function that satisfies the differential equation:

$$
T^{\prime \prime}(z) T(z)-3\left[T^{\prime}(z)\right]^{2}=0
$$

Given the general solution of equation (3) and boundary conditions $T_{2}\left(H+h_{1}\right)=R_{1}$ i $T_{2}\left(h_{1}\right)=R_{2}$, finally we get:

$$
N_{\partial 2}=\pi \sigma_{S} R_{1}^{2}\left(V_{0}+W_{2}\right)\left[\begin{array}{l}
C_{1} R_{1}^{2} H+2 \ln \frac{R_{2}}{R_{1}}- \\
-C_{2}\left(R_{2}^{2}-R_{1}^{2}\right)- \\
-C_{1} h_{1}\left(R_{2}^{2}-R_{1}^{2}\right)
\end{array}\right],
$$

where $T_{2}(z)=\frac{1}{\sqrt{C_{1} \cdot z+C_{2}}} ; C_{1}=\frac{R_{2}^{2}-R_{1}^{2}}{R_{1}^{2} R_{2}^{2} H}$;

$C_{2}=1 / R_{2}^{2}-C_{1} h_{1}$.

Thus, the main difficulties of calculations of the axial kinematic module with an inclined curvilinear boundary (4) are overcome. Calculations of power of shear forces on the inclined and upper limits do not cause difficulties. This leaves open the question of the use of the keystone module in workflows that contain the adjacent lower modules of various configurations. Also, an important question arises the possibility of optimizing the full value of the reduced pressure of the entire design scheme, including the kinematic parameter $W_{2}$. The axial trapezoidal module 1 under consideration is internal, so let us consider it in combination with the lower module of varieties $2 \mathrm{a}, 2 \mathrm{~b}$ and $2 \mathrm{c}$. The configurations of the adjacent module 2 and KPVF in table 1 are presented.

Of interest is the analysis of the magnitude of the power shear forces between module 1 and the possible configurations of module 2 :

$$
\begin{aligned}
& N_{c 1 i_{-} 2 a}=\frac{2 \pi \sigma_{s}}{3 \sqrt{3}}\left|\begin{array}{l}
W_{2}\left(\frac{R_{2}}{2 h_{1}}\left(R_{2}^{2}-R_{1}^{2}\right)-K_{i} R_{1}^{2}\right) \mid- \\
-V_{0} R_{1}^{2}\left(K_{i}+\frac{R_{2}}{2 h_{1}}\right)
\end{array}\right|, \\
& N_{c 1 i_{-} 2 b}=-\frac{2 \pi \sigma_{s}}{3 \sqrt{3}}\left(V_{0}+W_{2}\right) K_{i} R_{1}^{2}, \\
& N_{c 1 i_{-} 2 a}=\frac{2 \pi \sigma_{s}}{3 \sqrt{3}}\left[V_{0} R_{1}^{2} G-W_{2}\left(R_{2}^{2} G+K_{i} R_{1}^{2}\right)\right],
\end{aligned}
$$

where $K_{i}=\left.T_{i}^{\prime}(z)\right|_{z=h_{1}} ; G=\frac{R_{2}-R_{1}}{h_{1}}$.

For the rectilinear boundary of module 1 in the form $T_{1}(z)$ we use $K_{1}=\left(R_{1}-R_{2}\right) / H$. For a curved incli- ned boundary of the view $T_{2}(z)$ we use $K_{2}=-C_{1} R_{2}^{3} / 2$, where $C_{1}=\left(R_{2}^{2}-R_{1}^{2}\right) /\left(R_{1}^{2} R_{2}^{2} H\right)$. Further calculations are carried out in relative terms $\bar{R}_{2}=R_{2} / R_{1}, \bar{H}=H / R_{1}, \bar{h}_{1}=h_{1} / R_{1}, \bar{R}_{3}=R_{3} / R_{1}$.

Table 1. Configuration and KPVF of adjacent kinematic module 2

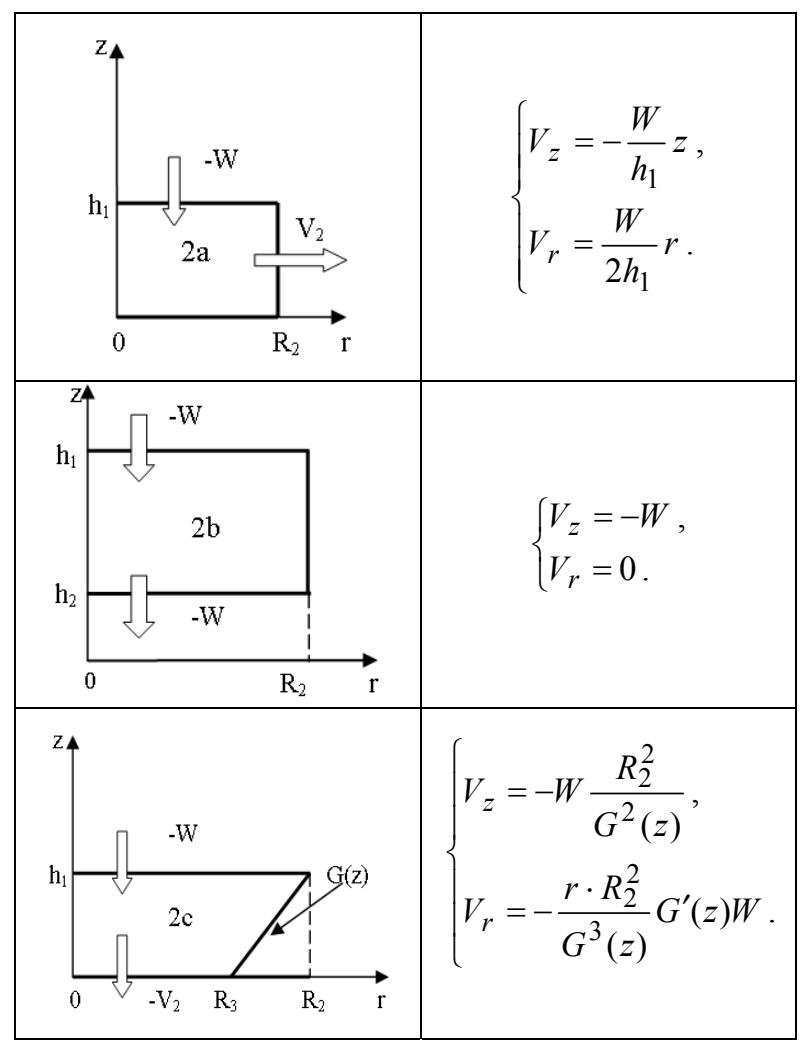

We pass for dimensionless quantities $\bar{p}_{c 1 i_{-} 2 j}=$ $=N c_{c 1 i_{-} 2 j} / \pi \sigma_{S} V_{0} R_{1}^{2}$, where $i=1$ corresponds to the limit $T_{1}(z), i=2-\operatorname{limit} T_{2}(z)$, and $j$ depending on the configuration of the module 2 takes the value $a, b, c$ respectively, for (5) - (7). Let's analyze the dependencies $\bar{p}_{c 1 i_{-} 2 j}$ from relative kinematic parameter $\bar{W}_{2}=W_{2} / V_{0}$ (Figure 2).

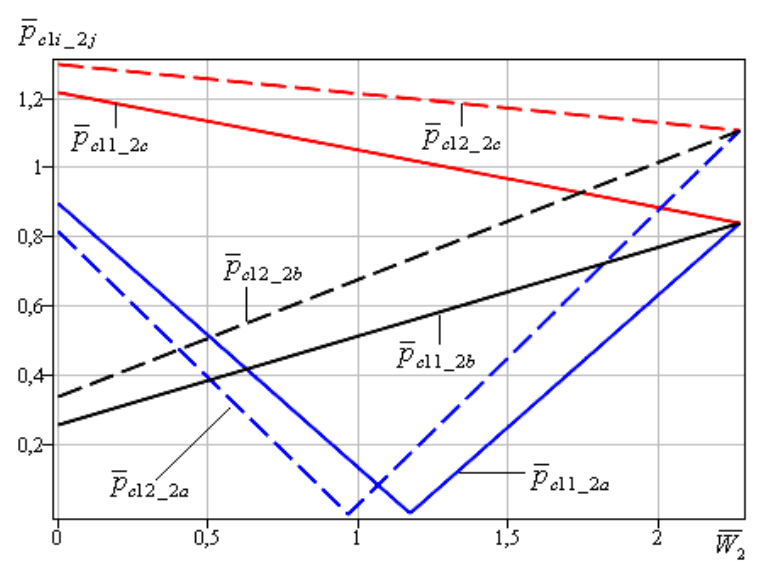

Figure 2. Comparative analysis of reduced pressure of the shear forces $\bar{p}_{c 1 i_{-} 2 j}$ from $\bar{W}_{2}$ by $\bar{R}_{2}=1.2, \bar{R}_{3}=0.7$, $\bar{H}=0.3, \bar{h}_{1}=0.2$ 
The nature of the change in the reduced pressure and shear forces for the straight (solid line) and curved (dotted line) boundaries of the kinematic module 1 does not change by maintaining of the configuration of the module 2 . With the growth of $\bar{W}_{2}$ the functions $\bar{p}_{c 11 \_b}$ and $\bar{p}_{c 12 \_2 b}$ grow monotonously, but $\bar{p}_{c 11 \_2 c}$ and $\bar{p}_{c 12 \_2 c}$ monotonously fall. The curvilinear boundary $T_{2}(z)$ corresponds to a higher value of the value $\bar{p}_{c 12 \_2 b}$ i $\bar{p}_{c 12 \_2 c}$ in comparison with the values $\bar{p}_{c 11 \_2 b}$ i $\bar{p}_{c 11_{-} 2 c}$ respectively. Thus, the use of the kinematic parameter $\bar{W}_{2}$ as variation is impossible.

Character of change of values $\bar{p}_{c 11_{-} 2 a}$ i $\bar{p}_{c 12 \_2 a}$ radically different from those obtained above. These functions are characterized by the presence of a minimum point-a point that satisfies the condition $\bar{p}_{c 11 \_2 a}=0$ by $K_{1}=\left(R_{1}-R_{2}\right) / H$ and $\bar{p}_{c 12 \_2 a}=0$ by $K_{2}=-C_{1} R_{2}^{3} / 2$. For a curved inclined boundary, the optimal value $\bar{W}_{2}$ shifts in the direction of decreasing this value. Thus, the use of relative velocity $\bar{W}_{2}$ as a variable parameter is possible. This optimization is possible only when combining kinematic modules with a set of radial velocity components $V_{r}$ one direction (sign) for both adjacent modules and not possible in other cases. Indeed, for the entire volume of module 1 for any form of boundary $T_{1}(z)$ or $T_{2}(z)$ we have $V_{r}=-r R_{1}^{2} T^{\prime}(z)\left(V_{0}+W_{2}\right) / T^{3}(z)>0$ and for module 2 as $2 \mathrm{a}$ is made the condition $V_{r}=W r / 2 / h>0$. For combinations of module 1 and modules $2 \mathrm{~b}$ and $2 \mathrm{c}$, this condition did not meet. Under the condition of radial components of one direction (sign) in adjacent modules 1 and $2 \mathrm{a}$, calculations of the combined radialbackward extrusion process are carried out (Figure .3).

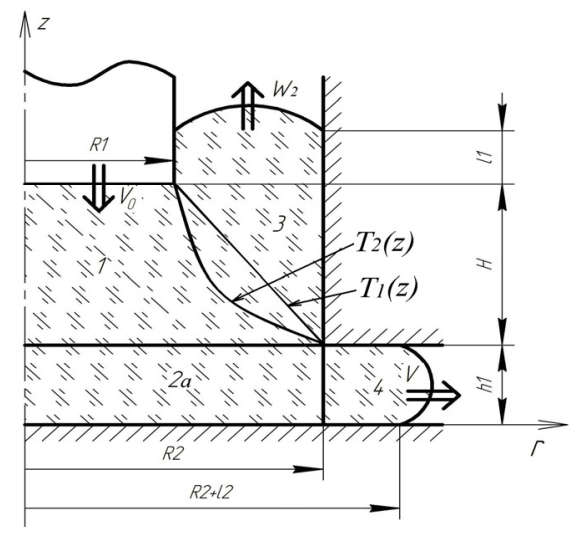

Figure 3. Calculation scheme of the process of combined radial-backward extrusion

In paper [19] the value of the reduced pressure $\bar{p}$ taking into account the optimization for kinematic parameter $\bar{W}_{2 o p t}$ is obtained:

$$
\bar{W}_{2 o p t}=\frac{R_{1}^{2} H-h_{1}\left(R_{2}^{2}-R_{1}^{2}\right)}{\left(R_{2}^{2}-R_{1}^{2}\right)\left(H+h_{1}\right)} .
$$

Given the optimal value $\bar{W}_{2 o p t}$ according to (8), we obtained data on the increase in the size of the semifinished product in the vertical $\Delta l_{1} \uparrow$ and radial $\Delta l_{2} \rightarrow$ directions in the course of the deformation process at the initial height $H_{0}$ :

$$
\left\{\begin{array}{l}
\Delta l_{1} \uparrow=\frac{1}{R_{2}^{2}-R_{1}^{2}}\left(R_{1}^{2} \Delta H x+h_{1} R_{2}^{2} \ln \left|1-\frac{\Delta H x}{H_{0}}\right|\right), \\
\Delta l_{2} \rightarrow=\sqrt{\frac{R_{1}^{2} \Delta H x-\left(R_{2}^{2}-R_{1}^{2}\right) l_{1} \uparrow}{h_{1}}+R_{2}^{2}}-R_{2} .
\end{array}\right.
$$

A comparative analysis of this deformation process in the presence of rectilinear and curvilinear inclined boundaries of the kinematic module 2 is carried out. The comparative analysis of theoretically and experimentally obtained data showed the reliability of the optimization results by the kinematic parameter $\bar{W}_{2}$.

Overvaluation of the theoretically obtained results for the energy-power parameters of the process $\left(R_{1}=10.5 \mathrm{~mm}, R_{2}=1 \mathrm{~mm}, h_{1}=3 \mathrm{~mm}, H_{0}=17 \mathrm{~mm}\right)$ does not exceed $10 \quad 15 \%$ (Figure 4 ).

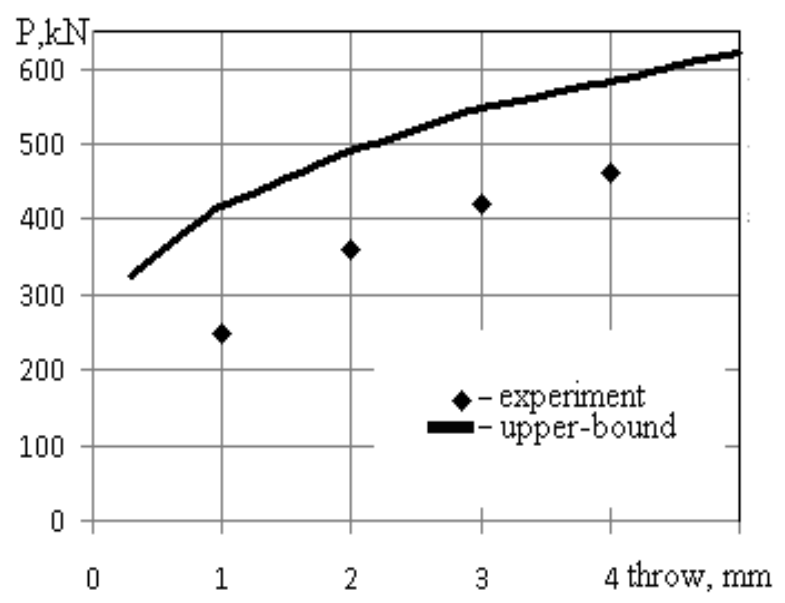

Figure 4. Comparative analysis of experimental and of theoretical data on the extrusion effort due from a press stroke for material C46400

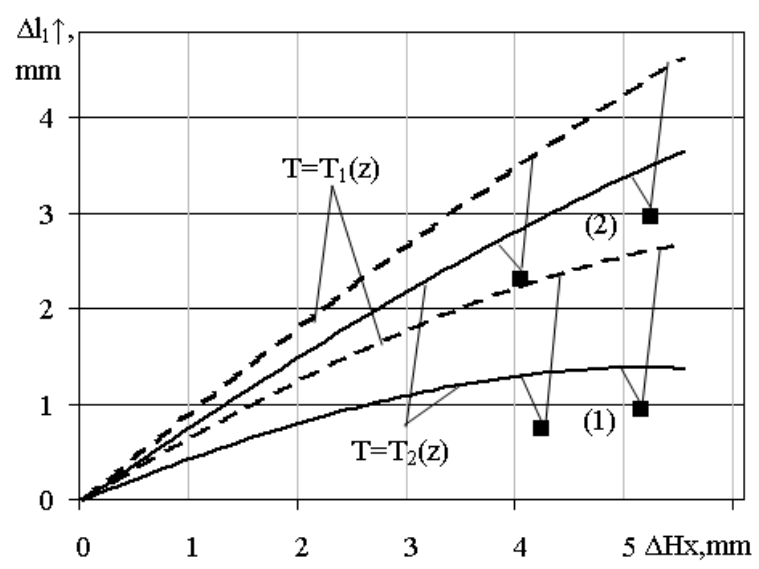

Figure 5. Comparative analysis of increments of dimensions of a semi-finished product at $T=T_{1}(z)$ and $T=T_{2}(z)$

Comparative analysis of increments of a semifinished product was performed for (1): $R_{1}=10.5 \mathrm{~mm}$, 
$R_{2}=14 \mathrm{~mm}, h_{1}=5 \mathrm{~mm}, H_{0}=14 \mathrm{~mm}$ and (2): $R_{1}=10.5 \mathrm{~mm}$, $R_{2}=14 \mathrm{~mm}, h_{1}=3 \mathrm{~mm}, H_{0}=14 \mathrm{~mm}$, based on the proposed theoretical assessments with point data obtained by modeling in Qform2D/3D (Figure 5).

The deviation of magnitude $\Delta l_{1} \uparrow$ throughout the entire deformation process for $T=T_{2}(z)$ indicates the smallest deviation compared to $T=T_{1}(z)$ from the point data obtained by modeling in Qform2D/3D [19].

At the same time, optimization by kinematic parameter $\bar{W}_{2}$ for schemes with a disconnected deformation zones in the presence of a rigid zone of type $2 b$ no results were obtained [22].

\section{CONCLUSIONS}

The present paper has developed the novel engineering computations for power of shearing force for the combination of the axial trapezoidal module with the lower module of common configurations. Engineering conditions of usage of kinematical parameter of outlet metal velocity as optimization parameter have been found for the first time. The authors' approach provides possibility to derive the optimized value of dimensionless extrusion pressure, related energy-power characteristics and deformation-induced plastic form change for the processes of combined extrusion with the several degrees of freedom of plastic flow.

The paper analyzes the features of using the axial trapezoidal module in the design schemes with an adjacent lower module of various configurations. As adjacent kinematic modules, a rectangular rigid, longitudinal-transverse flow and a trapezoidal kinematic module with a rectilinear inclined boundary are chosen. For each of the adjacent modules, the shear forces $N_{c 1 i_{-} 2 j}$ were obtained for each of the two types of the inclined boundary of the axial trapezoidal module. These values are analyzed as functions of the kinematic parameter $\bar{W}_{2}$ - the relative velocity of the metal flow in the backward direction. The presence of a minimum point of dimensionless quantities $\bar{p}_{c 11 \_2 a}$, corresponding to $N_{c 1 i_{-} 2 a}$, indicates the possibility of optimization with respect to the relative metal flow velocity in the backward direction $\bar{W}_{2}$. The optimal value of the quantity $\bar{W}_{2}$ corresponds to the fulfillment of the condition that the power of the shear forces is equal to zero. It has been established that optimization with respect to the relative metal flow velocity in the backward direction is possible only with a combination of kinematic modules with a radial component $V_{r}$ of one direction (sign) and is impossible in other cases. The calculations of the combined radial - backward extrusion process $V_{r}$ are carried out under the condition of the same radial component direction $V_{r}$ in adjacent modules. The usage of the relative metal flow velocity in the backward direction as an optimization parameter was demonstrated. The comparative analysis of theoretical and experimental data and simulation results in Qform2D/3D was conducted. The deviation of the theoretically obtained estimates of the force parameters of the process and shaping does not exceed $10-15 \%$.

Author-proposed computations for the powers of shearing forces can be successfully used for engineering-friendly modeling of more complex processes of the cold combined extrusion with additional taking into account of availability of metal flow in the forward, backward and radial directions.

\section{REFERENCES}

[1] Zhang, S.H., Wang, Z.R., Wang, Z.T., Xu, Y. and Chen, K.B.: Some new features in the development of metal forming technology, Journal of Materials Processing Technology, Vol. 151, No. 1-3, pp. 3947, 2004, doi:10.1016/j.jmatprotec.2004.04.098.

[2] Aliev, I.S.: Radial extrusion processes, Soviet Forging and Sheet Metal Stamping Technology (English Translation of Kuznechno-Shtampovochnoe Proizvodstvo), No. 3, pp. 54-61, 1988.

[3] Aliev, I.S., Lobanov, A.I., Borisov, R.S. Savchinskij, I.G.: Investigation of die blocks with split matrixes for the processes of cross extrusion, Kuznechno-Shtampovochnoe Proizvodstvo (Obrabotka Metallov Davleniem), No. 8, pp. 21-26, 2004.

[4] Aliiev, I., Aliieva, L., Grudkina, N., Zhbankov, I.: Prediction of the variation of the form in the processes of extrusion, Metallurgical and Mining Industry, Vol. 3, No. 7, pp. 17-22, 2011.

[5] Aliev, I.S., Nosakov, A.A. and Makhmudov, K.D.: The method of kinematic modules for the analysis of precision die forging processes [Metod kinematicheskikh moduley dlya analiza protsessov tochnoy ob"emnoy shtampovki], in: Materials working by pressure [Sovershenstvovanie protsessov $i$ oborudovaniya obrabotki davleniem $v$ metallurgii i mashinostroenii: sb. nauch. trudov], Donbass State Engineering Academy, Kramatorsk, pp. 142-146, 2001. (in Russian).

[6] Kalyuzhnyi V.L., Alieva, L.I., Kartamyshev, D.A. and Savchinskii, I.G.: Simulation of Cold Extrusion of Hollow Parts, Metallurgist, Vol. 61, No. 5-6, pp. 359-365, 2017, doi:10.1007/s11015-017-0501-1.

[7] Lee, H.Y., Hwang, B.B., Lee, S.H.: Forming load and deformation energy in combined radial backward extrusion process, in: Mori, K., Pietrzyk, M., Kusiak, J. et al.: Metal Forming 2012: proceedings of the 14th International Conference on Metal forming, 16-19.09.2012, AGH University of Science and Technology, Krakow, pp. 487-490.

[8] Jafarzadeh, H. et al.: Numerical studies of some important design factors in radial-forward extrusion process, Materials and Manufacturing Processes, Vol. 25, No. 8, pp. 857-863, 2010, doi:10.1080/ 10426910903536741.

[9] Choi, H.-J. et al.: The forming characteristics of radial-backward extrusion, Journal of Materials Processing Technology, Vol. 113, No. 1-3, pp. 141147, 2001, doi:10.1016/ S0924-0136(01)00703-8.

[10] Jain, S.C, Bramley, A.N., Lee, C.H., Kobayashi, S.: Theory and experiment in extrusion forging, Adv. 
Mach. Tool. Des. and Res, Vol. B, pp. 1097-1115, 1970.

[11] Perig, A.V.: 2D upper bound analysis of ECAE through 2 $\theta$-dies for a range of channel angles, Materials Research-Ibero-American Journal of Materials, Vol. 17, No. 5, pp. 1226-1237, 2014, doi:10.1590/1516-1439.268114.

[12] Perig, A.: Two-parameter Rigid Block Approach to Upper Bound Analysis of Equal Channel Angular Extrusion through a Segal 20-die, Materials Research-Ibero-American Journal of Materials, Vol. 18, No. 3, pp. 628-638, 2015, doi: 10.1590/1516-1439.004215.

[13] Filippov, Yu.K., Ignatenko, V.N., Golovina, Z.S., Anyukhin, A.S., Ragulin, A.V., Gnevashev, D.A.: Theoretical study of the combined process of radial and backward extrusion in conical matrix [Teoreticheskoe issledovanie kombinirovannogo protsessa radial'nogo vyidavlivaniya v konicheskoy matritse], Kuznechno-Shtampovochnoe Proizvodstvo (Obrabotka Metallov Davleniem), No. 7., pp. 3-7, 2011. (in Russian).

[14]Filippov, Yu.K., Ignatenko, V.N., Golovina, Z.S., Ragulin, A.V., Anyukhin, A.S., Gnevashev, D.A.: Experimental study of metal flow in the combined process of radial and reverse extrusion in a conical matrix [Eksperimental'noe issledovanie techeniya metalla pri kombinirovannom protsesse radial'nogo i obratnogo vydavlivaniya v konicheskoy matritse], Kuznechno-Shtampovochnoe Proizvodstvo (Obrabotka Metallov Davleniem), No. 9., pp. 33-35, 2011. (in Russian).

[15] Perig, A.V., Zhbankov, I.G. and Palamarchuk, V.A.: Effect of Die Radii on Material Waste during Equal Channel Angular Extrusion, Materials and Manufacturing Processes, Vol. 28, No. 8, pp. 910915, 2013, doi:10.1080/10426914.2013.792420.

[16]Perig, A. V. and Matveyev, I. A.: FEM-Based Deformation Regression Analysis of ECAE Strains, FME Transactions, Vol.47, No.4, pp. 851-855, 2019, doi:10.5937/fmet1904851P.

[17] Stepansky, L. G.: Calculation of metal-forming processes [Raschetyi protsessov obrabotki metallov davleniem], Mashinostroenie, Moscow, 1979 (in Russian).

[18] Chudakov, P.D: O vychislenii moshchnosti plasticheskoy deformatcii, Izvestiya vuzov. Mashynostroenye, No. 7, pp. 146-148, 1979. (in Russian).

[19] Hrudkina, N. et al.: Derivation of engineering formulas in order to calculate energy-power parameters and a shape change in a semi-finished product in the process of combined extrusion, EasternEuropean Journal of Enterprise Technologies, Vol. 2, No. 7 (98), pp. 49-57, 2019, doi:10.15587 /1729-4061.2019.160585.

[20] Chudakov, P. Verhnyaya ocenka moshchnosti plasticheskoy deformatcii $\mathrm{s}$ ispol'zovaniem minimiziruyushchey funkcii, Izvestiya vuzov. Mashynostroenye, No. 9, pp. 13-15, 1992. (in Russian).
[21] Hrudkina, N., Aliieva, L. Abhari, P., Markov, O., Sukhovirska, L.: Investigating the process of shrinkage depression formation at the combined radial-backward extrusion of parts with a flange, Eastern-European Journal of Enterprise Technologies, Vol. 5, No. 1 (101), pp. 49-57, 2019, doi:10.15587/1729-4061.2019.179232.

[22] Vlasenko, K., Hrudkina, N., Reutova, I., Chumak O.: Development of calculation schemes for the combined extrusion to predict the shape formation of axisymmetric parts with a flange, EasternEuropean Journal of Enterprise Technologies, Vol. 3, No. 1 (93), pp. 51-59, 2018, doi:10.15587/1729-4061.2018.131766.

\section{NOMENCLATURE}

$V_{0} \quad$ Punch velocity, $[\mathrm{mm} / \mathrm{s}]$

$W \quad$ Velocity of the metal flow in the forward

direction, $[\mathrm{mm} / \mathrm{s}]$

$W_{2} \quad$ Velocity of the metal flow in the

backward direction, [ $\mathrm{mm} / \mathrm{s}$ ]

$h_{1} \quad$ Dimensional thickness of flange, [mm]

$H$ Dimensional height of module 1, [mm]

$R_{1} \quad$ Dimensional radius of punson, [mm]

$R_{2} \quad$ Dimensional radius of die, [mm]

$R_{3} \quad$ Dimensional radius of lower base of

$R_{3} \quad$ module $2 \mathrm{c},[\mathrm{mm}]$

$\sigma_{\mathrm{s}} \quad$ Yield point, [MPa]

$T_{i}(z) \quad$ Inclined boundary of the flow interface of

$V_{r} \quad$ Radial component of direction of KPVF,

$\begin{array}{lll}V_{r} & {[\mathrm{~mm} / \mathrm{s}]}\end{array}$

$N_{\partial} \quad$ Power of deformation forces, [mW]

$C_{1} \quad$ Auxiliary parameter, $\left[1 / \mathrm{mm}^{3}\right]$

$C_{2} \quad$ Auxiliary parameter, $\left[1 / \mathrm{mm}^{2}\right]$

$K_{i} \quad$ Dimensionless auxiliary parameter

$G \quad$ Dimensionless auxiliary parameter

$N_{c l i \_2 j} \quad$ Power shear forces, [mW]

$\bar{p}_{c l i 2 j} \quad$ Reduced dimensionless pressure of power

shear forces

$\Delta l_{1} \uparrow \quad$ Increase in size of semifinished product in

$\Delta l_{2} \rightarrow \quad$ Increase in size of semifinished product in radial, $[\mathrm{mm}]$

\section{Abbreviations}

CVF Cold Volume Forging

KPVF Kinematically Possible Velocity Field

FEM Finite Element Method

\section{МОДЕЛИРАЊЕ ПРОЦЕСА ХЛАДНЕ ЕКСТРУЗИЈЕ ПРИМЕНОМ КИНЕМАТИЧКИХ ТРАПЕЗОИДНИХ МОДУЛА}

\section{Н.С. Хрудкина, Л.И. Алииева}

Анализирају се карактеристике коришћења аксијалног трапезоидног модула на шемама дизајнирања са суседним доњим модулом различитих конфигурација. За суседне кинематичке модуле изабран је 
правоугли крути лонгитудинални попречни проток и трапезоидни кинематики модул са праволинијском границом под нагибом. Утврђено је да је оптимизација релативне брзине протока метала у смеру уназад могућа само у комбинацији кинематичких модула са радијалном компонентом једног правца, док је у осталим случајевима немогућа. Приказана је практична реализација приступа за посебан случај моделирања процеса комбинацијом екструзије радијално уназад крајњих делова са прирубницом. Одступање теоријски добијених прорачуна параметара силе код поступка и обликовања не прелази 10-15\%. Предложена израчунавања снаге сила смицања могу се успешно користити за техничко моделирање сложених процеса са хладном екструзијом, при чему се узима у обзир могућност течења метала у радијалном и правцу уназад и унапред. 